\title{
Cartas da Revolução Cubana: Reinaldo Arenas antes do exílio Mariel
}

\author{
Jorge Luiz Teixeira Ribas ${ }^{1}$
}

\begin{abstract}
Resumo: Este artigo se propõe a investigar a correspondência do escritor e poeta cubano Reinaldo Arenas (1943-1990) com seus amigos Jorge e Margarita Camacho, entre os anos 1967-1980, objetivando compreender a dinâmica de sua experiência nas duas primeiras décadas da Revolução Cubana. Arenas foi um intelectual censurado e perseguido por ser homossexual e pelo teor de seus escritos. Nesse período, atuou politicamente contra o autoritarismo por meio da escrita epistolar clandestina. Através de algumas de suas cartas, busca-se explorar os aspectos do pensamento político do escritor, seus posicionamentos, sua subjetividade, as ideias e os sentidos que produziu em relação às políticas revolucionárias, apontando o alcance e os limites das mesmas. Pretende-se, dessa forma, contribuir com as investigações sobre a trajetória do escritor antes de seu exílio pelo porto Mariel em 1980, bem como ressaltar a importância dessas fontes para a historiografia sobre o período, além de aprofundar a compreensão do contexto revolucionário no que se refere à relação entre os intelectuais e a revolução.
\end{abstract}

Palavras-chave: Reinaldo Arenas; Escrita epistolar; Revolução Cubana.

\section{Letters of the Cuban revolution: Reinaldo Arenas before the Mariel exile}

\begin{abstract}
This article take as a propose to investigate the correspondence of the Cuban writer and poet Reinaldo Arenas (1943-1990) with his friends, residents in France, Jorge and Margarita Camacho, between the years of 1967-1980, objectifying understand the dynamic of his experience in the first two decades of the Cuban revolution. Arenas was an intellectual censored and chased in Cuba for he was a homosexual and by the content of his writings. In this period he acted politically against the authoritarianism by illegal epistolary writing. By some of his letters, one seek to explore in his writing aspects of his political thinking, his positioning, his subjectivity, the ideas and meanings that he produced about the revolutionary politics, pointing, in his narrative, the reach and limits of them. It is searched, with that, to contribute to the investigations of the author's trajectory before the exile by the Mariel port in 1980, as well as to emphasize the importance of this sources to the historiography about the period, in addition to deepening the understanding of the revolutionary context, regarding the connection between intellectuals and the revolution.
\end{abstract}

Key-words: Reinaldo Arenas, epistolary writing, Cuban Revolution.

Artigo recebido em: 31/12/2017

Artigo aprovado para publicação em: 09/05/2018

\footnotetext{
${ }^{1}$ Mestre em História Social no Programa de Pós-Graduação em História da Universidade Estadual de Montes Claros - PPGH/Unimontes, Brasil. Título da pesquisa: Reinaldo Arenas: revolução, nação e homossexualidade em Cuba (1959-1980). Endereço para correspondência: Rua Álvaro Tolentino, $\mathrm{n}^{\circ}$ 90, bairro Dona Gregória - Montes Claros, MG - CEP: 39403-038. E-mail: jorge_luiz_moa@ @otmail.com. Pesquisa financiada pela CAPES.
}

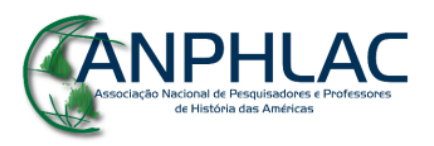

Revista Eletrônica da ANPHLAC, ISSN 1679-1061, №. 24, p. 219-252, Jan./Jun., 2018.

http://revista.anphlac.org.br 
Reinaldo Arenas nasceu em 1943, na província de Holguín, Cuba. Aos 15 anos, participou da luta insurrecional guerrilheira e da vitória revolucionária de 1959. Foi poeta, escritor, viu-se perseguido em função dos assuntos que abordava nos seus livros e por sua homossexualidade. Em 1974, foi preso e torturado. Após 1976, já completamente silenciado em Cuba, existindo como um escritor fantasma e impedido de sair do país, com a vida despedaçada, exilou-se pelo porto Mariel em 1980 e suicidou dez anos depois, em 1990, na cidade de Nova York. Arenas vivenciou os principais acontecimentos da revolução, e tanto sua escrita quanto sua sexualidade fizeram dele um contrarrevolucionário, na medida em que se adentrou a década de 1960 e a ditadura castrista restringiu as liberdades que em algum momento foram sonhadas e possíveis na aurora revolucionária. Censurado, preso, torturado, exilado, experimentou uma vida atravessada pela barbárie, fenômeno tão frequente no século XX sob diversos regimes políticos.

Neste artigo, abordaremos a escrita epistolar de Reinaldo Arenas, numa correspondência iniciada em 1967 e terminada em 1980, último ano em que esteve na ilha, com o casal de amigos residentes na França, Margarita Camacho e Jorge Camacho. Na verdade, a correspondência durou até o final de sua vida, em 1990, mas aqui serão apresentadas apenas algumas cartas que foram enviadas por ele enquanto esteve em Cuba, demonstrando o quanto a vida do escritor pode elucidar para a compreensão histórica do período, com suas complexidades, disputas, projetos que estiveram em jogo e se perderam no tempo, além do que, expressam uma subjetividade inquieta, em conflito com seu contexto, que não se resigna ou submete aos ditames de um regime autoritário, disciplinador, recriando-se diante dos desafios.

No conjunto, contam-se 23 cartas escritas nesse período para Jorge e Margarita das quais analisaremos apenas algumas com o objetivo de abordar as questões que inquietaram Arenas e que contribuem para a compreensão mais ampla de sua participação no seio da Revolução Cubana. O que interessa aqui é discutir como o escritor se apresenta nessa correspondência, o que se pode extrair de suas posturas políticas e, na medida do possível, das implicações de sua sexualidade na repressão que sofreu, de maneira a investigar a experiência de Reinaldo Arenas enquanto um escritor, homossexual, em Cuba durante as duas primeiras décadas da revolução, apontando, assim, a importância desse tipo de fonte para a compreensão do contexto, bem como a

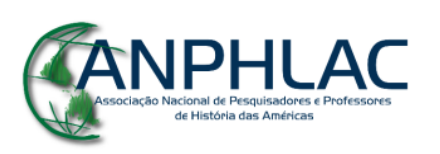

Revista Eletrônica da ANPHLAC, ISSN 1679-1061, №. 24, p. 219-252, Jan./Jun., 2018.

http://revista.anphlac.org.br 
prática da escrita como lugar de expressão e conformação de uma subjetividade, de resistência, de liberdade, onde se revelam valores, significados, sensações, medos e sonhos de quem viveu um determinado período, cujas marcas, com o passar do tempo, quando recontadas, tomam dimensões diferentes.

Reinaldo, Margarita e Jorge se conheceram em 1967, na cidade de Havana, capital cubana, e o casal de amigos se tornou, imediatamente, a grande esperança para o escritor, incorporando o sonho de liberdade fora da prisão em que se sentia viver e a possibilidade de ver suas obras publicadas, mesmo fora da ilha, alcançando a visibilidade, a possibilidade de circulação de seus talentos literários. Enquanto esteve em Cuba, contudo, não se tratou de uma correspondência regular, de maneira que não se estruturou um diálogo coeso e continuado, mas intermitente, por razões do perigo que envolvia a intenção de sair de Cuba, publicar obras que não fossem consonantes com a ideologia do regime, ainda mais se tratando de um escritor homossexual. Assim, há um considerável espaço de tempo entre as cartas, muitas não obtiveram respostas, as que foram respondidas pelos amigos não foram preservadas e, portanto, não foram publicadas.

Pelo menos no Brasil, ainda não foi tomado conhecimento de nenhuma pesquisa que tenha abordado essas cartas em seu conjunto e desenvolvido algum trabalho de investigação sobre elas. É provável que esta fase primária da análise se deva ao fato de que foram publicadas recentemente, em 2010, na Espanha, compiladas no livro Cartas a Margarita y Jorge Camacho (1967-1990), pelo editorial Point de Lunettes, sendo sua única edição e disponibilidade para o grande público. Portanto, trata-se aqui dos primeiros passos de exploração da escrita epistolar de Arenas, que tem uma configuração muito específica, motivações diferentes das que fundamentaram suas outras obras já exploradas em outras pesquisas, pois possui uma marcação temporal precisa ao mesmo tempo que fraturada: entre uma carta e outra, às vezes, há o intervalo de quase um ano ou até mais. Isso porque as cartas precisavam ser contrabandeadas, escondidas, escritas em situações bastante improváveis por seu conteúdo explosivo. Outras vezes, o silêncio entre uma correspondência e outra foi marcado pelo encarceramento do escritor. Várias cartas, juntas de outros manuscritos do escritor, foram levadas para fora de Cuba por amigos, conhecidos e turistas que visitavam a ilha e se dispunham a fazer a ponte entre Arenas, Jorge e Margarita. À exceção de alguns

\section{GANPHLAC}


outros documentos anexados ao montante, as cartas publicadas foram apenas as de autoria de Reinaldo Arenas.

Escritas por uma razão em comum, ou seja, a posição vulnerável do escritor que se viu como opositor ao regime cubano, mantendo, com muita coragem, seu hábito de escrita, essas cartas atestam o conflito entre o escritor e o regime. A problematização das políticas revolucionárias, do sentido da palavra revolução, a audácia em tratar de certos assuntos em seus livros, a publicação no exterior de suas obras, a esperança de sair da ilha e alcançar um lugar em que pudesse escrever, pensar e amar livremente nos apresentam uma história da Revolução Cubana com a qual não estamos acostumados.

Além dessas motivações que o levam a escrever, as cartas configuram um corpus muito específico devido às condições de sua produção, pois, tendo a publicação de seus escritos recusadas, como foi o caso da novela El mundo alucinante (1967), e experimentando viver uma sexualidade condenada e proibida, como conta em sua autobiografia Antes que anoiteça (1995), estava imerso na sombra do autoritarismo e suas variantes: perseguição, silenciamento das divergências, prisão, tortura, o limite da morte. Além de uma prática de escrita de si como lugar de resistência, de afirmação de uma subjetividade que se recusa a se apagar, as cartas de Arenas também são redutos de testemunho, nas quais não nos preocupam os costumes cotidianos, os traços de sociabilidade (embora isso possa ser explorado), mas as situações-limite vivenciadas por ele: esclarecer como sua experiência em praticar uma escrita e sexualidade consideradas dissidentes, quando a homossexualidade foi um dos principais alvos do processo de purificação revolucionária, influiu na sua visão de mundo, decisões, na sua dinâmica existencial e na narrativa. A estratégia de escrever as cartas e enviá-las, muitas vezes, através de amigos e turistas, atestam os riscos assumidos pelo escritor como também refletem o recrudescimento do autoritarismo em Cuba, que condiciona a produção da escrita.

As cartas apresentam sentidos que denotam uma variação de interpretações do repertório simbólico revolucionário. Apontam para fissuras, deslocamentos, distâncias. E mais, o fato de precisarem ser contrabandeadas, escondidas, zeladas com cuidado e com atenção ao perigo, indica a repressão que havia sobre quem não estava no mesmo tino dos ideais oficiais do regime. As cartas de Reinaldo Arenas representam uma subjetividade que se tentou silenciar, uma manifestação do eu que foi negada, a

$$
\text { CANPHLAC }
$$


violência simbólica e física de alguém que não se enquadrava nas normas, na conveniência da moral e nas rígidas molduras ideológicas. Sua fuga de Cuba em 1980 não se deu por outra coisa.

Dessa forma, pelas posições e ideias que fundamentam a narrativa epistolar de Arenas, inscreve-se no campo ideológico uma autonomia crítica que demonstra a complexidade do contexto em que viveu, que não foi homogêneo, revelam as diferentes formas de experimentá-lo e dimensionam diferentes expectativas. No limite, a escrita epistolar permite ainda sondar os aspectos da relação entre os intelectuais e a revolução com base na experiência subterrânea de Arenas que esteve, neste período, distante das consagradas revistas de circulação literária.

Enquanto esteve em Cuba, o escritor não participou efetivamente dos debates no interior das principais publicações pós-revolucionárias, como Lunes de Revolución, La Gaceta de Cuba, Casa de las Américas, Unión, El Caimán Barbudo, Pensamiento Crítico, que foram objetos de pesquisas historiográficas. Talvez por uma questão etária, já que Arenas tinha 17 anos em 1960 quando chegou a Havana, além do que, ele se despontaria no ambiente literário somente entre 1965 e 1966, com a publicação de sua novela Celestino antes del alba (1965) e com a menção honrosa a El mundo alucinante (1966) no concurso da Uneac (Unión de Escritores y Artistas de Cuba), quando conheceu escritores de renome nacional como Lezama Lima e Virgílio Piñera.

Por Reinaldo Arenas não ter feito parte do corpo editorial de nenhuma revista cubana importante - esse lugar privilegiado de "fermentação intelectual", como apontou Sirinelli (2003) -, sua atuação no período anterior ao exílio permanece obscurecida. Mas a ausência do escritor dos meios mais consolidados do debate intelectual não nos impede de travar uma investigação dentro das noções de "itinerário", "geração" e "sociabilidade", indicadas por Sirinelli (2003) para a análise dos intelectuais. Pois, em suas cartas, é notável o engajamento de Reinaldo Arenas nas questões políticas de seu tempo, revelando seu itinerário pela tomada de posição diante dos desafios enfrentados. Há também indícios de convivência com outros intelectuais, como José Lezama Lima, quem várias vezes é lembrado, coisa que sugere a sociabilidade entre escritores, posto que se reuniam para debater as medidas do regime revolucionário a respeito da criação literária. Além disso, Reinaldo Arenas se insere também na mesma geração do heterogêneo grupo intelectual articulado em torno de um acontecimento fundador: a

$$
\text { CANPHLAC }
$$

Revista Eletrônica da ANPHLAC, ISSN 1679-1061, №. 24, p. 219-252, Jan./Jun., 2018.

http://revista.anphlac.org.br 
revolução. Na correlação entre esses pontos, o papel de Arenas vai se abrindo, o engajamento possível do intelectual passa a girar em torno da liberdade de expressão e da liberdade sexual em Cuba, por meio da escrita epistolar e da ficção literária.

Em $1^{\circ}$ de dezembro de 1967 , na primeira carta direcionada ao amigo Jorge Camacho, algo já inquieta profundamente o escritor. "Todo eso te lo digo para informarte”, escreve hesitante, "aunque aquí mismo hay una confusión tremenda y no sé que harán con los escritores. En fin, esperamos que todo se resuelva de la forma más humana" (ARENAS, 2010, p. 29). Retrospectivamente, essas palavras indicam um terrível prenúncio. Como mencionamos acima, em 1966, sua novela El mundo Alucinante, que trata de uma aventura fabulosa e satírica de um líder nacionalista mexicano, o frei Servando Tereza de Mier y Noriega (1763-1827), em busca da libertação do México do julgo espanhol, recebeu menção honrosa no concurso da Uneac. Porém, fora impedido de ser publicado, sob a acusação de ser demasiadamente homossexual... À altura de 1967, Reinado Arenas era um escritor temente do destino que se guardava aos escritores e se sensibilizava com as mudanças políticas porque passavam os meios literários em Cuba. Neste ano, o regime revolucionário discutia suprimir os direitos de autor no país, por ser uma propriedade privada, ao tempo que se procurava enquadrar o que deveria ser escrito e publicado na ilha de acordo a ortodoxia revolucionária. As orientações políticas para a participação dos intelectuais e os critérios da produção literária foram definidas pouco tempo depois desta carta de Arenas no $I$ Congreso Cultural de la Habana, ocorrido em janeiro de 1968 (MISKULIN, 2008, p. 49). Dentro das diretrizes para a produção literária, noções moralistas da sociedade foram incisivas. Nos problemas de perseguição e censura que Arenas enfrentou, a sexualidade estava diretamente envolvida nas decisões do regime em reprimi-lo. Numa sociedade em que os ícones revolucionários eram modelos de homens heterossexuais, os comportamentos sexuais sofreram interferência de políticas normatizadoras nas quais os homossexuais foram considerados abjetos contrarrevolucionários (ALBUQUERQUE JR, 2009). Essas questões, mesmo que não ditas diretamente, estão implícitas e dão o contorno de sua escrita.

$\mathrm{Na}$ medida em que avançava a década de 1960, o policromático campo intelectual atuante enfrentava diretrizes revolucionárias sobre autonomia e produção literárias que restringiam a liberdade dos escritores, e os direitos do autor, enquanto

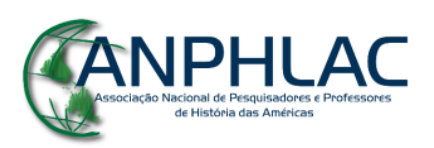

Revista Eletrônica da ANPHLAC, ISSN 1679-1061, №. 24, p. 219-252, Jan./Jun., 2018.

http://revista.anphlac.org.br 
propriedade privada, foram estatizados, ao tempo em que aumentava os mecanismos de controle político. Quando Arenas escreve "esperamos que todo se resuelva de la forma más humana" (ARENAS, 2010, p. 29), o "esperamos", de "nós esperamos", revela uma mobilização coletiva, o envolvimento de mais escritores desconfortáveis diante das arbitrariedades e de sua condição instável. "Creo que es conveniente decirte", continua Arenas, "que en los seminarios del Congreso Cultural (que fueron tremendamente mediocres) se aprobó (sin contar con los escritores) por la alta burocracia, que jamás ha escrito una cuartilla, eliminar los derechos de autor" (ARENAS, 2010, p. 29).

Após a criação do Partido Comunista em 1965, a centralização do poder nas mãos do Partido e seu Líder Máximo foi progressiva. O âmbito das políticas culturais neste cenário foi orientado por intelectuais e agentes culturais ligados à ortodoxia partidária que se tornaram hegemônicos no quadro da burocracia do governo. Intelectuais e artistas declaradamente ligados às políticas do regime contribuíram para o enquadramento da participação dos intelectuais em geral, na medida em que se apagava a miríade de ideias presentes no início da década (ROJAS, 2008). Assim, a burocracia que Reinaldo Arenas critica era, em grande parte, formada por intelectuais afeitos à ortodoxia de que se constituiu as políticas do regime.

Desde os primeiros anos da revolução, a participação dos intelectuais esteve em disputa; seu destino sob o regime revolucionário foi conflituoso devido à progressiva centralização das decisões a respeito dos assuntos culturais e comportamentais. A figura do carismático Comandante en Jefe foi problematizada por Reinaldo: "Eso, desde luego, estaba aprobrado mucho antes por Fidel, y todo no fue más que una pantomima representativa" (ARENAS, 2010, p. 29). Se Fidel teve um enorme apoio popular, pelo menos nas palavras de Arenas, a unanimidade em torno do líder é posta em questão. E o motivo disso está longe de ser algum saudosismo pré-revolucionário, a defesa do capitalismo ou rancor e oposição ao movimento revolucionário em si.

As palavras de Reinaldo Arenas nessa missiva são ecos de quase uma década de centralização e cerceamento das liberdades criativas que ele focaliza no ditador. $O$ próprio recurso das cartas clandestinas para se comunicar e promover suas críticas é sintomático desse processo. Mas tal crítica deve ser entendida dentro de um fenômeno mais geral quando foram articuladas medidas em que as produções artísticas que não traduzissem as transformações e maravilhas revolucionárias, à maneira de panfleto, para

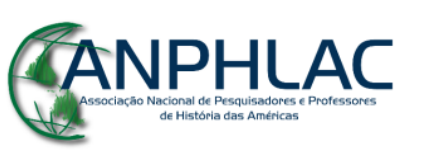

Revista Eletrônica da ANPHLAC, ISSN 1679-1061, №. 24, p. 219-252, Jan./Jun., 2018.

http://revista.anphlac.org.br 
educação das massas e publicações convenientes no exterior, recebiam o olhar desconfiado dos patrulhadores do que eram consideradas posturas contrarrevolucionárias. Nesse ínterim, a afirmação de subjetividades, individualidade, o exercício da imaginação e as visões de mundo dissonantes da imposta pelo governo revolucionário foram condenados à margem do silêncio nesse período (MISKULIN, 2009).

No mesmo ano de 1967, não obstante os riscos que este ato envolvia, Arenas contrabandeou sua novela El mundo alucinante através de seus amigos Jorge e Margarita, que veio a ser publicada na França em 1969. Ele sofreria sérias consequências em função dessa atitude subversiva de publicar uma obra sem a permissão do órgão oficial responsável pelas publicações, a Uneac. De toda forma, o fato de enviar para o exterior uma novela pela impossibilidade de ser publicada em seu país - por motivações claramente homofóbicas e políticas - fê-lo por excelência um contrarrevolucionário. Os desdobramentos desse episódio dão o tom à sua correspondência: suas cartas são envoltas de sigilo, contrabandeadas; nelas, apresenta-se um escritor preocupado, sensível ao enrijecimento do regime e à arbitrariedade do autoritarismo, ciente da situação crítica em que se metia.

É assim que o rasgo do presente aparece em suas linhas na carta de 9 de dezembro de 1967, as estratégias de ação, a reação, a insubmissão ao que lhe é imposto: “debido a la situación actual aquí [...] Eso, en ese momento y con todas las dificultades que parecen venir para que los escritores puedan publicar sus obras, me parece lo más conveniente" (ARENAS, 2010, p. 32). Trata-se do plano de que Jorge Camacho o representasse no exterior para preservação dos seus direitos autorais fora de Cuba. As dificuldades para publicar na ilha são de diversos fatores, mas todos convergidos numa mesma questão: ou se adequa à visão de mundo do regime revolucionário, ou vive-se à margem. Ou se vive como prega o regime, ou sofrerá a violência simbólica do silenciamento.

A ortodoxia ideológica não se restringiu à esfera política, mas também sexual. As expressões de sexualidade que não fossem pautadas na heteronormatividade, do homem másculo, viril, ativo, que o guerrilheiro veio a simbolizar, indicavam uma inadequação ao corpo revolucionário (TEIXEIRA, 2009). E este era o caso de El mundo alucinante, com várias cenas de sexo não convencional entre homens, por exemplo, em

\section{GANPHLAC}


meio a uma missão nacionalista de Frei Servando, missão patriótica, de orgulho nacional, tema-base dos infindáveis discursos de Fidel Castro. Este também era o caso do próprio Arenas, declaradamente homossexual, com uma vida atravessada intensamente de práticas homoeróticas (ARENAS, 1995).

Publicar um livro, para Arenas, significava defender uma ideia e também existir por meio dela. E parece que isso se tornava ainda mais imperativo num momento em que as expressões de ideais e de modos de viver eram enquadradas por um projeto político hegemônico que se impôs pela revolução. Até seu último dia em Cuba, Arenas não seria perdoado por sua rebeldia. O indivíduo que fala por si, não em nome de toda uma coletividade imaginada como portadora de verdades universais, mas preservando a sua individualidade, era considerado um egoísta pequeno-burguês. Além disso, a homossexualidade foi classificada como um comportamento por excelência contrário às virtudes revolucionárias (YOUNG, 1984). A esses considerados desvios burgueses, vícios decadentes, ambos incorporados por Arenas, seria necessário a reconversão à luz da única verdade dos dirigentes comunistas. Numa entrevista concedida por Fidel a Lockwood em 1965, ele declarou a respeito dos homossexuais:

\footnotetext{
Nada impede um homossexual de professar a ideologia revolucionária e, portanto, exibir uma postura política correta. No entanto, não temos como crer que um homossexual personifique as condições e condutas necessárias para possibilitar que o consideremos um verdadeiro revolucionário. Um desvio dessa natureza vai contra o conceito que temos de como um militante comunista deve ser (Apud CHOMSKY, 2015, p. 185-186).
}

Em poucas palavras, o que Fidel disse acima é que o homossexual deveria negar sua homossexualidade; contudo, em nenhuma hipótese poderia ser um sujeito político no interior da revolução, por se desviar da natureza revolucionária ideal sedimentada na heterossexualidade do homem viril e ativo.

É necessário dizer que, malgrado a tendência de Fidel Castro em se confundir com a revolução, sendo impreterivelmente o último a dar a palavra e dono das decisões burocráticas, seja do campo da cultura ou da política administrativa, isso não implicava um necessário apoio dos intelectuais engajados nas transformações de seu tempo ao dote centralizador do tirano, nem mesmo a enxergar nele e sua equipe comunista a única expressão revolucionária. Ao menos na primeira década, até aproximadamente 1968, a revolução ainda inspirava mobilizações diversas, com diferentes formas de adesão que

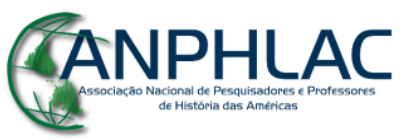

Revista Eletrônica da ANPHLAC, ISSN 1679-1061, №. 24, p. 219-252, Jan./Jun., 2018.

http://revista.anphlac.org.br 
não se explicam no binômio oficial revolução-contrarrevolução (MISKULIN, 2008; 2009). As formas de adesão e participação compõem uma zona cinzenta que nenhuma análise poderia deixar de levar em conta sem cair no reducionismo. Uma margem de liberdade ainda ocorria na sociedade em construção, sendo a participação dos intelectuais, portanto, intensa e, até onde pôde, difusa. É nessa direção que interpretamos outro trecho dessa mesma carta de dezembro de 1967, onde, ao denunciar o que julga uma arbitrariedade do regime, Reinaldo Arenas traz também a presença de seu amigo Lezama Lima, escritor homossexual, cujo livro Paradiso, de 1966, que Arenas descreveu em suas memórias como "uma novela tão violentamente homossexual" (ARENAS, 1995, p. 114), foi retirado de circulação:

[...] la perspectiva que hay para los autores parece un poco oscura, pues todos los trámites para las publicaciones estarán a cargo de los organismos burocráticos (el autor no cuenta) y esos organismos serían los que dan la aprobación de las publicaciones y seleccionarían la obra que ellos estimen conveniente publicar en el extranjero.

De manera que en mi caso y en el de Lezama, esto será fatal, porque aunque nosotros estamos profundamente ligados a la Revolución, no le hacemos el juego a los funcionarios mezquinos que administran la cultura y ocupan cargos decisivos. Los mismos rasgos surrealistas de mis novelas serían un obstáculo más para que las dieran a conocer, pues aquí se está en pro de un realismo limitadísimo que por otra parte nada tiene que ver con la verdadera realidad. Yo tuve que escribir un artículo a la Unión ${ }^{2}$ defendiendo lo que yo estimo por el verdadero realismo, pues me criticaron de surrealista y de vivir en las nubes. (ARENAS, 2010, p. 33)

Não nos deteremos aqui a definir o que seria o surrealismo ao qual Arenas se refere, porque o termo era, de certa forma, utilizado de maneira bastante imprecisa. Mas podemos afirmar que se tratava de uma criação de portas abertas à imaginação, na qual se recorre a aspectos do maravilhoso, como foi discutido detidamente por Altamir Botoso (2011) para o caso de El mundo alucinante, que pouco tempo antes desta carta havia sido contrabandeado para a França. O que nos interessa realçar é a afirmação pelo escritor da possibilidade de uma diferente narrativa da realidade, de sua descrição e apropriação independente da "realidade objetiva" imposta pelo regime sob a alcunha de "realismo socialista", em que deveriam ser apontadas as fissuras e desigualdades da sociedade pelo viés da luta de classes, indicando o caminho da superação da exploração

\footnotetext{
${ }^{2}$ Refere-se à Unión del Escritores y artistas de Cuba (UNEAC).

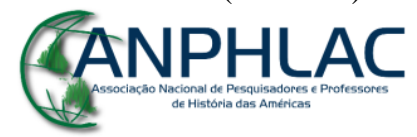

Revista Eletrônica da ANPHLAC, ISSN 1679-1061, №. 24, p. 219-252, Jan./Jun., 2018.

http://revista.anphlac.org.br
} 
pela revolução e o socialismo oficial ${ }^{3}$. A contenda entre a visão institucional da literatura e a do escritor é demonstrada quando Arenas defende a sua própria narrativa como mais próxima da realidade, por ser plural e dinâmica, do que a narrativa propagandística defendida pelo regime. Foi acusado por isso, pejorativamente, de ser surrealista e de viver nas nuvens.

Nota-se ainda que criticar a burocracia revolucionária não significa ser contrário à revolução, daí a afirmação de que Arenas e Lezama eram "profundamente ligados a la Revolución” parecer ambígua. Ainda tendo em vista os ânimos revolucionários do momento, em que o regime não havia sofrido os fortes impactos desmoralizantes que o esperava ${ }^{4}$, nem mesmo Arenas havia vivido o pior, uma dose de sinceridade nessa afirmação é bastante plausível. No entanto, os motivos pelos quais Arenas insinuou criticar as decisões revolucionárias sobre a produção literária eram suficientes para ser considerado contrarrevolucionário. De toda forma, para ele, a visão ideológica hegemônica não fazia jus em representar o real, por suas restrições e limitações representativas, ao tempo que, em sua concepção, a realidade deveria ser tal como as variadas expressões dos seres, complexas e heterogêneas, contingente. E assim seguiu em defesa.

Observa-se, assim, que tanto Lezama Lima como Reinaldo Arenas participaram da revolução. Os temas tratados por Arenas em suas cartas conectam-no ao debate travado por diversos outros intelectuais que atuaram na cena revolucionária: realismo socialista, ortodoxia ideológica, o papel dos intelectuais, o conteúdo das obras, burocracia. Contudo, o debate ideológico sobre os rumos da revolução que mobilizou

\footnotetext{
${ }^{3}$ Ambrosio Fornet (2007, p. 5) definiu, de forma breve, o realismo socialista como "la literatura como pedagogía y hagiografía, orientada metodologicamente hacia la creación de heróes positivios y la estratégica ausencia de conflitos antagónicos en el seno del pueblo".

${ }^{4}$ O final da década de 1960 foi de fortes revezes para a revolução e foi marcado pela acentuação do autoritarismo do regime: a morte de Che Guevara em outubro de 1967, na Bolívia, sinalizava os limites do método guerrilheiro como forma de luta revolucionária; as dificuldades econômicas do país, agravadas pelo bloqueio econômico imposto pelos EUA, reforçou a aproximação e dependência com a URSS, junto com a adoção de políticas soviéticas na condução da economia da ilha, como a radical planificação econômica pela desapropriação de pequenos comerciantes. A aproximação com a URSS e seus métodos político-econômicos foi coroada ainda pela defesa pública de Fidel Castro à invasão soviética à Tchecoslováquia em 1968. No interior do regime, a "Ofensiva Revolucionária" que mobilizou milhares de cubanos para o trabalho nas plantações de cana-de-açúcar para que fosse alcançada uma safra de 10 milhões de toneladas em 1970, que permitiria alavancar a economia e superar o subdesenvolvimento, fracassou. Além de toda a exaustão causada por esse processo, acompanhada pelo recrudescimento do autoritarismo, no campo cultural, até princípios de 1971, a vanguarda revolucionária estaria quase completamente afastada das decisões revolucionárias e perdia espaço nas disputas internas de poder para os ortodoxos (FORNET, 2007; MISKULIN, 2008).
}

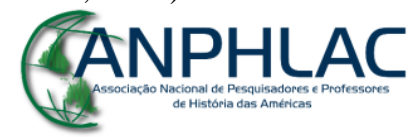

Revista Eletrônica da ANPHLAC, ISSN 1679-1061, №. 24, p. 219-252, Jan./Jun., 2018.

http://revista.anphlac.org.br 
Arenas não se resume às questões literárias em si, mas se direcionam, mesmo indiretamente, a todo o repertório simbólico erigido desde os tempos da Sierra Maestra. O otimismo, disposição e sacrifício pela revolução, para alcançar as metas produtivas mirabolantes tão urgentes nas plantações de cana, coisas que caracterizariam o homem novo, o sujeito utópico que habitaria a sociedade perfeita ${ }^{5}$, não estão presentes, por exemplo, quando o escritor trata desse assunto com seus amigos. Nem mesmo alguma expressão de orgulho, como se pode ver neste trecho de uma carta de 13 de abril de 1969. “Querido Camacho”, escreve:

Casi corriendo te hago estas líneas. Me encuentro trabajando en el campo durante este mes de abril, Jornada de Girón, en este año que como sabes es el del "Esfuerzo Decisivo". [...] Estoy terriblemente cansado y te escribo aprovechando la tarde de este domingo, ya de verano intolerable, que no he tenido que trabajar en el campo pues estamos de permiso. (ARENAS, 2010, p. 40)

O ano do "Esfuerzo Decisivo" foi, no calendário revolucionário, o período motivacional de trabalhos "voluntários" nas monoculturas de cana que duravam semanas, para alcançar a meta de 10 milhões de sacas de açúcar, numa tentativa desesperada de alavancar a economia da ilha e melhorar a balança comercial com a URSS. Fidel Castro promoveu uma forte campanha nacional de trabalho voluntário, em meio à sucessão de metas frustradas, mas incentivado pelos próprios líderes que divulgavam fotografias sujos e suados no campo como trabalhadores comuns, representando o sacrifício individual pelo bem coletivo, de maneira a elevar o otimismo e o senso patriótico revolucionário. Por conseguinte, durante esse tempo, a ofensiva gerou um grande saldo simbólico, com os estímulos morais que entrelaçavam consciência política revolucionária, cultura e economia. As demandas nacionais

\footnotetext{
5 O homem novo, cujo principal porta-voz em Cuba foi Che Guevara, seria produto da sociedade revolucionária e um projeto de arquitetura humana. Seria a conformação do indivíduo que, pela mudança de consciência, de comportamento e por meio de uma nova relação com o trabalho proporcionado pela revolução, construiria uma nova sociedade, não apenas pela implantação de um novo modo de produção que não fosse capitalista, mas, principalmente, pela construção de uma nova moral, que permitiria a consolidação da sociedade utópica. O homem novo é, sobretudo, uma nova condição moral com força de superar as amarras do passado. Assim, a tarefa primordial da revolução era criar o homem novo pela libertação do indivíduo das explorações e alienações da sociedade capitalista. O homem novo seria, assim, o criador da sociedade perfeita, proveniente não das relações burguesas, mas da classe operária, da classe camponesa, enquanto classes ideais para promover a transformação revolucionária (GUEVARA, 1980).
}

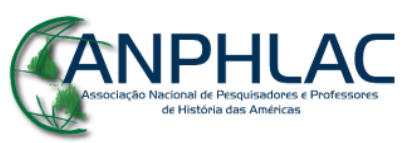

Revista Eletrônica da ANPHLAC, ISSN 1679-1061, №. 24, p. 219-252, Jan./Jun., 2018.

http://revista.anphlac.org.br 
estimularam uma intensa produção de discursos reforçando o trabalho braçal como prioridade e que conferia a dignidade do revolucionário. Mas a imposição ideológica e a intolerância política acompanharam essas medidas do governo para desenvolver novas relações sociais de produção que fossem diferentes da economia capitalista. A valorização do trabalhador braçal, constituído de otimismo, ânimo, dedicação total e mudança de consciência, colocava efetivamente em prática a concepção do homem novo, de maneira a realizar junto às demandas prementes da revolução, a própria consolidação dessa utopia. Nesse quadro, de acordo com o desempenho do trabalhador, evidenciaram-se divisões que marcavam uns como mais revolucionários que outros. Indivíduos que se recusavam a participar desses trabalhos sofriam uma série de represálias, como demissão de cargos de empregos e o recebimento da alcunha de contrarrevolucionários (VASCONCELOS, 2016, p. 37).

O impulso às metas produtivas, de esforço, sacrifício das forças físicas (tão valorizadas) à revolução é respondido por Arenas com o cansaço de uma rotina que lhe rouba o tempo que, ao contrário, deseja dedicar à produção literária. O que poderia ser uma exigência de um revolucionário representante estatal responsável pela safra, o seguinte trecho, "creo que hay que plantearse metas más desgarradoras, más sinceras, más intolerables y desconsoladoras, más arriesgadas [...]”, refere-se, na verdade, às metas literárias de Arenas declaradas a Jorge Camacho. E encerra: "Quisiera leer tanto y tengo tan poco tiempo. Quisiera escribir tanto y sin embargo estoy tan cansado" (ARENAS, 2010, p. 40). Arenas demonstra-se muito mais interessado na produção literária que açucareira. Se traz para a narrativa relatos sobre o trabalho no campo e sobre a esfera econômica da revolução, é para ressentir-se e, em seguida, depositar seu zelo e disposição na importância que nutre pela escrita. É como se o seu desejo pela escrita fosse interrompido pelas tarefas obrigatórias da revolução. Che Guevara e Fidel Castro constantemente dedicaram sua retórica para tentar convencer da glória que havia em estimar o trabalho braçal em detrimento de devaneios intelectuais, separando nitidamente as duas esferas. No máximo, o equilíbrio entre os dois: trabalhar para a revolução e pensar para a revolução (COSTA, 2009, p. 186-191).

Um breve parêntesis se faz necessário aqui. Com o advento da revolução em 1959, nenhum símbolo revolucionário superava o do guerrilheiro da Sierra Maestra. Em torno desse símbolo, estabelecia-se a identidade da coletividade revolucionária de

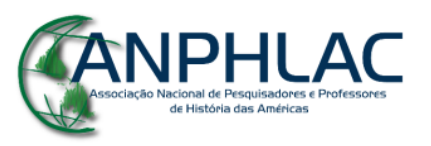

Revista Eletrônica da ANPHLAC, ISSN 1679-1061, №. 24, p. 219-252, Jan./Jun., 2018.

http://revista.anphlac.org.br 
toda a ilha, como foco de coesão, modelo de condutas, referência de agir e estar no mundo. A carga simbólica do guerrilheiro trouxe consigo um papel pedagógico imenso na missão de "formar almas" (CARVALHO, 1990) revolucionárias na nova sociedade em construção, incutindo valores, virtudes, maneiras de pensar, proceder etc. $\mathrm{O}$ guerrilheiro significava, entre outras coisas, o ímpeto patriótico, a defesa nacional, a hierarquia, independência, disciplina, coerência. Um verdadeiro ethos revolucionário que se cumpria na figura masculina destacada do homem viril, forte, em que noções de força e sacrifício eram preceitos indispensáveis. A estrutura extremamente masculinizada das colunas da guerrilha, composta sobretudo por homens, reforçaram a ligação de tais preceitos morais de conduta ao papel cumprido pelo homem na sociedade machista, de dominação masculina (TEIXEIRA, 2009).

A concepção de valorização do revolucionário como um homem másculo, bravo, valente, corajoso e heterossexual durante a guerrilha configura, bem afirmou Ian Lumsden (1996), uma das pedras fundamentais para a ação discriminatória dos homossexuais na Cuba revolucionária, pois os homossexuais supostamente careciam dos traços que tornavam o homem a figura privilegiada entre os sexos e apto às missões de engrandecimento da pátria (Apud TEIXEIRA, 2009, p. 167). O homossexual era uma ausência, a falta de masculinidade e, por extensão, de senso patriótico que, afinal, é supostamente inerente ao sujeito masculino heterossexual. Num contexto determinante para a história do país, mergulhado na missão de defender a revolução das ameaças imperialistas, atento aos aterrorizantes rumores de invasão estrangeira, dedicado à superação do subdesenvolvimento através do impulso ao trabalho, além da covardia que era atribuída aos homossexuais e afeminados - categorias que se sobrepunham -, esses sujeitos foram considerados elos frágeis, desqualificados para a guerra, desprovidos de ímpeto e vigor; inadequados, portanto, para a construção da integridade e independência da nação. A não incorporação dos afeminados e homossexuais na comunidade imaginada nacional na história de Cuba, vale dizer, é antiga; a segregação vem desde o século XIX (MADERO, 2005; ROBAINA, 2005; BEJEL, 2006) e foram reatualizadas no século XX de forma espetacular. Em poucas palavras, seguindo Benedict Anderson (2008), uma nação é imaginada enquanto comunidade porque a narrativa nacionalista constitui símbolos e significados sobre a vida e os indivíduos que, através deles, sentem-se pertencentes a uma coletividade homogênea. No contexto da revolução e da

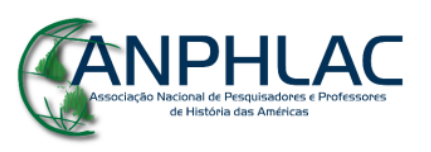

Revista Eletrônica da ANPHLAC, ISSN 1679-1061, №. 24, p. 219-252, Jan./Jun., 2018.

http://revista.anphlac.org.br 
hegemonia do símbolo guerrilheiro, ter as ações e condutas pautadas nos seus significados era uma forma de se integrar ao corpo nacional, pertencer a uma coletividade. O homem barbudo, fardado e armado continha os três artefatos que fabricaram o conceito de masculinidade cubana na segunda metade do século XX no qual os homossexuais eram deliberadamente excluídos.

O símbolo do guerrilheiro contribui para estruturar uma noção de indivíduo e, por conseguinte, de sociedade, de corpo da nação; ele oferece formas de vida e pautas políticas de comportamentos morais e sexuais que direcionam a conduta da população. Embora o discurso nacionalista seja voltado para toda uma massa a priori disforme, seu campo de ação causou efeitos desde o nível individual. O objetivo é transformar cada indivíduo e inseri-lo numa engrenagem de homogeneização para alcançar uma sociedade coesa e coerente, identificada em si mesma, onde todos se reconhecem num padrão, em que não há espaço para o "outro" senão na margem, na negligência, num ponto escuro em que se convive intimamente com a violência. É um mecanismo próprio da dinâmica autoritária do fenômeno nacionalista, o estabelecimento circunstancial de uma identidade baseada na exclusão do "outro", do diferente, seja ele de fora ou de dentro das fronteiras nacionais, sobre o qual exerce sua eficácia. Junto às representações positivas da guerrilha, desde que Fidel Castro declarou a revolução como de caráter comunista em 1961, concebeu-se um objetivo de arquitetura humana sobre o qual tornaria possível e se sustentaria a utopia guerrilheira: a formação do "homem novo" à cubana. Uma linha e continuidade concebiam a transferência da estrutura de funcionamento da guerrilha (com sua hierarquia, moral e ética sacrificial) para o desempenho de cada indivíduo na sociedade nova (TEIXEIRA, 2009). O homem novo era a condição para que a nova sociedade socialista vigorasse. Caberia ao homem novo a defesa da nação revolucionária e a construção do socialismo nos mínimos atos cotidianos, no trabalho, no pensamento, nas condutas, na moral, na sexualidade.

Hannah Arendt (2008) já havia chamado a atenção desde os anos 1950 quando discutiu a relação da ideologia com os processos políticos para o fenômeno social em que há a associação entre poder e os aspectos associados ao masculino, como força e dominação, traduzindo esses comportamentos morais em leis, segregando e descartando da vida política o que não se enquadra. As diferentes expressões de individualidade são

\section{GANPHLAC}


obscurecidas pela imposição de uma lógica irredutivelmente coletiva e homogeneizadora em termos patrióticos.

Em vários momentos da década de 1960, os opositores políticos ao regime cubano não foram apenas os ideologicamente contrários ao socialismo ou ao regime de Fidel Castro, mas tudo o que fora visto como desviante a esse modelo acima descrito: homossexuais, vadios, hippies, Testemunhas de Jeová, roqueiros, homens de cabelos cumpridos (BARRETO, 2004, p. 158-159; MISKULIN, 2013, p. 143; CHOMSKY, 2014, p. 187). Estes, por mais que não apresentassem ideias políticas contrárias à revolução, eram considerados contrarrevolucionários por não se submeterem aos critérios de masculinidade e trabalho condensados no homem novo e no guerrilheiro. Muitos foram enviados para as UMAPs, Unidades Militares de Apoio à Produção, campos de trabalho forçado que existiram na década de 1960, para que, por meio do trabalho braçal, do sacrifício, e da presença de homens heterossexuais, pudessem se voltar aos desejos de um verdadeiro revolucionário e se convertessem ao espírito do homem novo.

O que se pode notar nas cartas de Arenas é que os ideais da revolução, junto às demandas em alcançar metas econômicas no trabalho, dignos do revolucionário sob o regime de Castro, o que proporcionaria a libertação e mudança de consciência do sujeito, para não dizer enquadramento, através do esforço, disposição, combate aos valores morais e materiais considerados burgueses, não encontram expressão em suas linhas. Arenas não responde a elas positivamente, no otimismo sem limites disseminado pela propaganda oficial, mas o inverso disso. De outro modo, portanto, as cartas de Reinaldo Arenas lançam luz a respeito de um contexto bastante obscuro da revolução, pouco lembrado e nada romântico dos conflitos que diversos escritores enfrentaram nesse período. Os sentimentos e sensações que se apreendem do que narra Arenas são de descontentamento, desconforto, desânimo e desesperança nos anos de 1960 e 1970.

Por uma série de fatores internos e externos que movimentaram a política nacional de Cuba, vivia-se desde 1968 o maior grau de autoritarismo do regime. Os dinâmicos debates culturais de outrora a respeito de projetos de revolução e perspectivas possíveis, esperançosas e diversas, passavam paulatinamente a ser uma lembrança distante no decorrer da década de 1970, quando diversos intelectuais foram vítimas da parametración, como Heberto Padilla, Virgílio Piñera e o próprio Reinaldo Arenas.

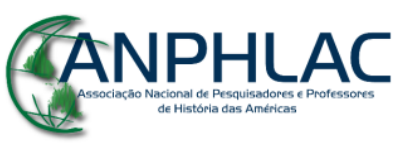

Revista Eletrônica da ANPHLAC, ISSN 1679-1061, №. 24, p. 219-252, Jan./Jun., 2018.

http://revista.anphlac.org.br 
Ambrosio Fornet (2006) chamou esse período de quinquênio gris, e Mario Coyula (2006) dimensionaria o fenômeno numa escala temporal ainda maior, restrito não apenas aos anos de 1970, mas situando o recrudescimento do regime já na aurora revolucionária, de 1960 até 1975, num trinquênio amargo.

A revolução havia se tornado uma máquina de metas econômicas e militares, sufocando as manifestações culturais que não fossem diretamente concordantes com a ideologia dominante. A censura, a vigilância e a intolerância formaram o modus operandi do regime. Cuba se tornara uma ditadura revolucionária cada vez mais dependente da União Soviética e agia a seu estilo, tanto pelo controle da literatura, quanto pelo lugar ocupado pelos comunistas no corpo político, mas também pelas políticas de perseguição a diversos sujeitos considerados desafetos ideológicos. 1968 é um marco divisor de águas na relação entre o regime e as políticas culturais (MISKULIN, 2008). O recrudescimento foi tão marcante a ponto de desestabilizar o romantismo da esquerda internacional, quando vários apoiadores distanciaram-se de Fidel após este apoiar abertamente a sangrenta invasão soviética da Tchecoslováquia naquele ano, numa atitude extremamente dócil em relação à Moscou, haja vista as dificuldades econômicas da ilha. A centralização do poder em torno de Fidel Castro e do Partido Comunista atrelada ao desafio de superar o bloqueio econômico da ilha, ao se aproximar da URSS, tiveram um reflexo direto nas liberdades do país.

Malgrado essas circunstâncias, Arenas não abriu mão da escrita, que tomou um tom muito mais direto nas críticas ao regime nesse contexto, como é o caso da novela Otra vez el mar (2015), que estava sendo escrita nesse período, onde praticamente nenhuma instituição criada pelo regime permanece de pé. Nessa novela é contada a história de Héctor, codinome para o próprio autor, que se trata de um revolucionário desencantado com a revolução e com inclinações homoeróticas. Evidentemente, Arenas estava consciente dos perigos que rodeavam a ousadia de insultar as autoridades revolucionárias e a própria revolução, além de insistir nas representações do homoerotismo entre seus personagens. Por isso, escreveu-a preventivamente com a finalidade de ser contrabandeada.

Em carta datada de 13 de abril de 1969, Reinaldo Arenas informa a Jorge Camacho que estava escrevendo Otra vez el mar. O autor fará menção novamente à novela somente três anos depois, na carta de 17 de novembro de 1972, endereçada a

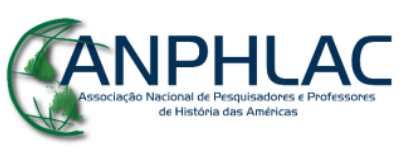

Revista Eletrônica da ANPHLAC, ISSN 1679-1061, №. 24, p. 219-252, Jan./Jun., 2018.

http://revista.anphlac.org.br 
Margarita: "Me alegra también enormemente que te haya gustado esa novela del mar" (ARENAS, 2010, p. 62. Grifos meus). Na carta de 30 de abril de 1973, o manuscrito novamente é assunto da correspondência:

\begin{abstract}
Mi querida Margarita,
He recibido dos cartas tuyas, la primera (una postal) en la que me hablas de la novela que acabas de leer y lo mucho que te había impresionado. Me alegra enormemente haber recibido esas noticias. Según he podido averiguar esa obra aún está incompleta, faltándole la segunda parte, que está hecha en forma de cantos. Guárdenla, pues, así como los sonetos de los que me hablas. Su autor, hablándome sobre ese tema, me dijo que eso se publicaría cuando él, ya en París, pudiese revisar las pruebas de los libros. Él ruega que lo guarden y lo cuiden como su vida o más, y saquen algunas copias de esas obras. (ARENAS, 2010, p. 64)
\end{abstract}

A trajetória dos manuscritos de Otra vez el mar é bastante elucidativa dos desafios enfrentados pelo seu autor na virada da década. Esta novela teve de ser reescrita duas vezes até ser efetivamente enviada para o exterior em meados da década de 1970. Sua primeira versão foi entregue ao cubano Aurélio Cortés, um amigo de Arenas provavelmente menos vigiado pela polícia e que poderia ajudar a contrabandeála. Contudo, Cortés, que era homossexual, sentiu-se ofendido por uma passagem no Canto 6 da novela em que fora caracterizado por Arenas como o Santa Maricas e ameaçou entregar o manuscrito à Segurança de Estado. Arenas tentou de todas as formas resgatar o manuscrito, mas sem sucesso. Deu-se então a escrevê-lo novamente e o escondia agora no teto da casa onde morava. Contudo, no período em que Arenas esteve preso (1974-1976), a Segurança de Estado encontrou o esconderijo e apreendeu o manuscrito. Após sair da prisão em 1976, Arenas escreveria pela terceira vez a novela e conseguiu, enfim, enviá-la a Jorge e Margarita por meio de dois turistas franceses (ARENAS, 1995, p. 150-153; 276-278).

Reinaldo Arenas se refere sempre de maneira indireta à sua própria novela, ele não informa o título e nem assume a autoria, quando a trata por "esa novela del mar" e refere a si mesmo em terceira pessoa, como "su autor (...) me dijo". Trata-se de uma estratégia do escritor para burlar a vigilância, caso suas cartas fossem vistoriadas. A novela fora escrita propriamente para ser contrabandeada e Arenas tinha ciência da dificuldade deste procedimento. Isso é sintomático do reconhecimento, por parte de Arenas, do grau de vigilância do regime sobre suas atividades; o escritor suspeitava de que estivesse sendo vigiado, além de assumir a completa consciência da subversão de

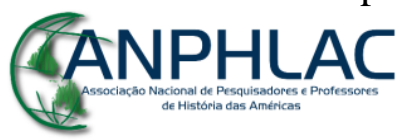

Revista Eletrônica da ANPHLAC, ISSN 1679-1061, №. 24, p. 219-252, Jan./Jun., 2018.

http://revista.anphlac.org.br 
seus escritos contra a ideologia do regime. Otra vez el mar foi concebida num momento de maior radicalidade da revolução, quando se aprofundava a "Ofensiva Revolucionária" dos trabalhos nas plantações e colheitas de cana, acompanhado da mais alta repressão política que abriu a década de 1970 na ilha. ${ }^{6}$

Arenas articulava em sua vida, dessa forma, duas esferas que estavam na mira do regime: os intelectuais e os homossexuais. Os primeiros deveriam servir para dizer como os outros deviam pensar, os segundos para apontar como os homens não deviam ser. Sua atitude em subverter ambas as esferas, a do pensamento e a da sexualidade oficiais, configura, no mínimo, um ato de extrema coragem, sem dúvida. A escrita é o campo para sua maneira de resistir, encontrando nas palavras e no papel uma maneira de indignar-se, liberar sua fúria, expressar seu grito de liberdade ou a vontade de ser livre (FERNÁNDEZ, 2015).

Em uma carta muito específica, Reinaldo Arenas se delonga em expressar suas insatisfações. Trata-se da epístola de 28 de junho de 1970, a mais longa, em que apresenta a dinâmica do autoritarismo do regime em restringir todas as experiências e expressões a uma noção produtivista da vida, num paradoxo em que a liberdade é subjacente ao trabalho obrigatório, mas que ironicamente liberta, em detrimento de outras iniciativas e formas de produzir na vida. Edificou-se nesse contexto um Estado altamente burocratizado, centralizado e autoritário, gerido por um regime norteado por um aparato repressor de ideologias divergentes ou contrárias, numa tendência totalitária, convergindo toda a sociedade a pensar de maneira única, igualitária, homogênea, voltada para os objetivos de um sistema determinado a excluir qualquer sinal de contradição e oposição. Escreveu Arenas:

Comprendo además que los pueblos y los intelectuales de otros sitios también están asqueados de su realidad (pero no podemos olvidar que el hecho de que ellos puedan manifestar esa repulsión es un privilegio que no poseemos nosotros). (ARENAS, 2010, p. 49)

Arenas expressa sua insatisfação com o fechamento ideológico do regime que levou à restrição da margem de atuação crítica dos intelectuais num momento ainda em que a criação literária, caso não propagasse os ideais do regime, era questionada,

\footnotetext{
${ }^{6} \mathrm{O}$ conto Qué trine Eva e os livros de poesia El central e Morir en junio con la lengua fuera também foram escritos nesse período, como há indicações na carta de 13 de dezembro de 1971 (ARENAS, 2010, p. 49).
}

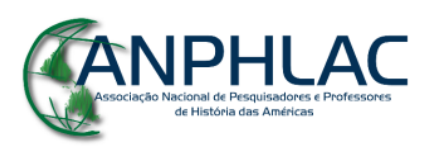

Revista Eletrônica da ANPHLAC, ISSN 1679-1061, №. 24, p. 219-252, Jan./Jun., 2018.

http://revista.anphlac.org.br 
suspeita de evasões individualistas, subterfúgios de devaneios desprendidos das urgências da revolução e da transformação social pelo trabalho braçal. Neste momento, a concepção de intelectual revolucionário em voga baseava-se nas ideias do francês Régis Debray, para quem o intelectual modelo e engajado se constituía pela sintonia entre ato e pensamento, mas atos e pensamentos que significavam agir e pensar em acordo com os ditames do regime, até mesmo porque os próprios Fidel Castro e Che Guevara eram, nessa concepção, modelos de intelectuais (COSTA, 2009, p. 188-191). No momento em que os trabalhos voluntários eram amplamente incentivados, o escritor deveria ser antes de mais nada um trabalhador braçal, que pensa e escreve a partir, e somente a partir, da revolução. Mas Arenas não é, definitivamente, subserviente a esse modelo, pois que se perguntou na carta:

[...] ¿qué porvenir tiene un escritor en un sitio donde cada palabra que escriba es revisada y vuelta revisar por un funcionario del sistema que considera la literatura como un medio para aumentar la producción o cantarle al Partido? (ARENAS, 2010, p. 49)

Enfim, é possível ver o embate travado pelo escritor que resiste e identificar em suas palavras ecos de uma década de políticas autoritárias e os efeitos de uma ideologia nacionalista revolucionária repressora. Desesperançado e ameaçado, nas correspondências seguintes, no início da década de 1970, Reinaldo Arenas chega ao seu limite, quando mais não poderia ser, e começa a tramar efetivamente sua fuga de Cuba. O plano foi chamado de "El libro de las flores", um código secreto para caso as cartas fossem apreendidas e vistoriadas. A primeira vez em que sua estratégia de fugir apareceu foi na carta escrita em 31 de dezembro de 1971: "También para 'El libro de las flores' deben ponerse de acuerdo con Durand", o editor responsável pelas obras de Arenas na França, amigo de Jorge e Margarita. Nesta mesma carta adicionou um postscriptum datado de 20 de fevereiro de 1972, porque ainda não havia enviado a carta, em que acrescenta: "Para 'El libro de las flores' deben ponerse de acuerdo con el editor Alberto Santos" (ARENAS, 2010, p. 56-57).

O ano de 1972 foi relativamente frutífero quanto à comunicação entre os amigos que cada vez incorporavam mais seu sonho de liberdade. Na carta de 14 de julho de 1972, relata sua imensa solidão dentro de Cuba quando admite que "mis mejores amigos son ustedes, Olga, Durand, por lo cual podrán imaginar que al menos

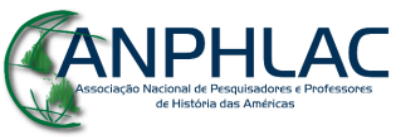

Revista Eletrônica da ANPHLAC, ISSN 1679-1061, №. 24, p. 219-252, Jan./Jun., 2018.

http://revista.anphlac.org.br 
fisicamente no estoy muy acompañado". Nenhum de seus melhores amigos é cubano, tamanho seu isolamento e os perigos que envolvem sua sociabilidade. Depois que Aurélio Cortés ameaçou denunciá-lo à polícia, os perigos de compartilhar seus projetos literários e políticos ficaram ainda mais patentes. Diante do risco de que seu plano de fuga fosse denunciado, provavelmente também não se atreveu a compartilhá-lo com muitas pessoas. Haja vista que a eficácia persecutória do regime aos desafetos ideológicos se deu em grande parte porque existiam verdadeiras redes de vigilâncias civis nas cidades, como os CDR (Comitês de Defesa da Revolução), em que a vizinhança, qualquer cidadão, responsabilizava-se a fiscalizar as pessoas em suas atividades cotidianas. Os homossexuais eram os principais alvos desses comitês (BARRETO, 1996, p. 144-145). Além do que, Arenas já havia sido vítima de amigos e parentes (ARENAS, 1995).

Nas passagens em que o escritor cita Olga, ela é sempre bem reverenciada, porque é uma mediadora do plano de fuga de Arenas e de seu próprio marido em suas viagens a Cuba, como se vê novamente citado na carta de 17 de novembro de 1972:

\footnotetext{
En cuanto al 'Libro de las flores' deben ponerse de acuerdo con Olga a fin de ver si ella ha hecho algún trámite para conseguirle algún editor. Es una obra de una importancia sin límites, como todas las grandes obras. [...] Ruego le entregues a Olga estas letras. (ARENAS, 2010, p. 63)
}

Em 30 de abril de 1973, “en cuanto al 'Livre des fleurs', creo que lo mejor que se puede hacer es ayudar a Olga, en cualquier aspecto, a fin de que ella pueda trabajar en él" (ARENAS, 2010, p. 65). Olga Neschein ainda enviaria uma carta para Jorge e Margarita, datada de 14 de maio de 1973 em que escreveu: "Una carta de ustedes, es muy importante para él ya que se encuentra muy aislado moralmente" (ARENAS, 2010, p. 365). Em outra carta sem data, Arenas pede que "ayúdenme pues en conseguir un libro muy importante que por acá no hay ni un ejemplar. Se titula 'El libro de las flores' (Le livre des fleurs)" (ARENAS, 2010, p. 61). Termina a carta de julho de 1972 indicando possíveis lugares para fugir: "Isla Sat, playas Panchita Picadillo, Rancho Veloz, Grande Inagma, Guaguacoao, Caracoa o Duraca” (AREAS, 2010, p. 60).

Em 12 de novembro de 1973, escreveu: "Espero pronto a Proust en francés, y la antologia poética sobre las flores ('Livre des fleurs') que no acabo de recibir" (ARENAS, 2010, p. 67); Em 13 de fevereiro de 1974, escreveu:

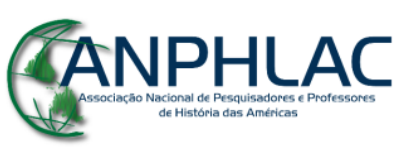

Revista Eletrônica da ANPHLAC, ISSN 1679-1061, №. 24, p. 219-252, Jan./Jun., 2018.

http://revista.anphlac.org.br 
Siempre lo que he deseado es un lugar solo y quieto donde poder hojear sin mucha precipitación a Proust, Rimbaud o al maravilloso 'Livre des fleurs' que espero. [...] Adiós, pero no para siempre, sino hasta la primavera, la 'Saison des fleurs', que pronto arribará a nuestra bella Isla. (ARENAS, 2010, p. 70)

Foi a última vez que Reinaldo fez referência ao livro das flores, seu plano de fuga. Este plano desesperado e perigoso reflete as mudanças políticas que Arenas experimentou em Cuba e também atesta sua subjetividade indisciplinada, com seu total desencanto em relação à revolução e uma esperança fatal pela liberdade fora dali. $\mathrm{O}$ ano de 1971 é visto por muitos pesquisadores como o maior marco de endurecimento do regime cubano, porque nele aconteceu o $1^{o}$ Congresso de Educação e Cultura (MISKULIN, 2009). De modo geral, discutiu-se nesse congresso o espaço destinado à cultura na sociedade em que foram definidas diretrizes oficiais administrativas em que se especificou, entre outras coisas, os responsáveis pelos projetos revolucionários, os ideais que deveriam ser disseminados e quem poderia ou não participar dos mesmos. $\mathrm{O}$ que nos interessa aqui e diz respeito diretamente ao nosso escritor é ressaltar as conclusões do Congresso a respeito da sexualidade em Cuba. As resoluções do Congresso definiram a homossexualidade como uma patologia social, os homossexuais foram caracterizados como "depravados incorrigíveis" cuja existência representava um flagelo a ser erradicado da sociedade revolucionária. O ideal de nação revolucionária e emancipada não comportava sujeitos que não se enquadravam numa fórmula pronta de homem heterossexual, baseado no símbolo guerrilheiro, como foi apontado acima. Não bastasse, nenhum homossexual poderia estar inserido em círculos culturais de Cuba por serem uma ameaça à juventude e por contaminar os jovens em formação, desviando-os da essência revolucionária (RESOLUÇÕES, 1980).

Ainda que Reinaldo Arenas não mencione sua homossexualidade nas cartas enviadas aos dois amigos, o escritor, que no início dos anos setenta trabalhava na biblioteca da UNEAC (Unión Nacional de Escritores y Artistas de Cuba), foi afetado duplamente por essas políticas. Além de ser um intelectual que divergia dos ideais do regime, sua homossexualidade tornava seu quadro ainda mais crítico e o deixava numa situação-limite. A repressão à homossexualidade ampliou ainda mais a vigilância sobre Arenas que estava sob observação, pode-se supor, desde ao menos 1968, com a

\section{GANPHLAC}


proibição da publicação de sua novela $E l$ mundo alucinante e por sua posterior publicação na França em 1969. A fuga foi o que lhe restou como última saída, a menos que abrisse mão de defender seu pensamento. A expressão do "Livro das flores" carrega um peso muito maior que, à primeira vista, transparece pelo que é dito nas cartas. Significa a decisão de um escritor homossexual a fugir do país onde, marginalizado, com todos os critérios para ser enquadrado como inimigo da revolução, não pôde escrever, pensar e tampouco amar livremente. Cada vez mais sozinho, solitário, tendo nos amigos estrangeiros sua única esperança, e seus livros seu motivo de vida, o mar lhe parecia o único caminho.

Mas a estratégia de fuga não vingou e Arenas não fugiu. Em 1974, passou pelas situações mais intoleráveis que são narradas em sua autobiografia Antes que anoiteça. Acusado de corruptor de menores (o estigma da pederastia que marca os homossexuais), extravagante, contrarrevolucionário, imoral, foi preso, conseguiu fugir se escondendo no Parque Lenin alguns dias, até ser preso novamente e encarcerado em El Morro e na Villa Marista, período em que tentou suicídio duas vezes. O diálogo entre os amigos só seria retomado em janeiro de 1976, ano em que saiu da prisão. Em 1980, quatro anos depois, Arenas foge de Cuba pelo porto Mariel.

A Revolução Cubana e seus desdobramentos instituíram, através do Partido Comunista único e centralizado, criado em 1965, uma expressão política de Estado que formulava, junto a uma articulação com valores e princípios presentes na sociedade, uma verdade e interpretação da realidade forçosamente "revolucionária", objetiva, situada numa suposta perspectiva das verdadeiras classes revolucionárias adaptadas à situação latino-americana, os camponeses e os operários. Da vanguarda revolucionária, a experiência guerrilheira, em detrimento das várias outras experiências e participações revolucionárias contemporâneas a ela, afirmou-se como baluarte dos novos hábitos, crenças, concepções de mundo, do masculino e feminino, das faculdades do pensamento, impondo isso à sociedade de modo geral, que deveria incorporá-los e superar os desvios pequeno-burgueses, apresentando um outro formato de vida pronto, estático e organizado. Essa dimensão disciplinar das práticas de militância (FIGUEIREDO, 1993) acabou por se sobrepor às outras experiências e experimentações que teriam possibilitado a produção e expressão diversificada de subjetividades livres e de relações sociais originadas no princípio da diferença.

\section{GANPHLAC}

Revista Eletrônica da ANPHLAC, ISSN 1679-1061, №. 24, p. 219-252, Jan./Jun., 2018.

http://revista.anphlac.org.br 
Assim que Reinaldo Arenas, ao escrever durante o período em que viveu sob a revolução, assume uma subjetividade que conflita com o projeto dominante imposto, disputa os sentidos considerados corretos, legítimos, como ironiza na epístola de 28 de junho de 1970: “Ah, para nosotros nos resultan extremadamente graciosas las palabras 'progresistas, 'futuro' o revolución.” Essas palavras indicam uma trajetória pessoal; as cartas informam sobre uma vida que diverge, um pensamento que se desprende da correnteza da maioria, visões de mundo que partem da experiência de quem prova, enfrenta, reage e se inventa pelo embate da vida e seus significados. Nesta mesma carta, escreveu sobre a revolução:

\begin{abstract}
ésta és una realidad tan extremadamente particular que hasta las palabras y las imágenes adquieren otras dimensiones distintas a las acostumbradas; el término, por ejemplo "planchar un campo de caña", tiene para nosotros, que nos hemos pasado meses en médio de este torbellino asfixiante, significaciones extremadamente precisas, únicas, que vistas desde fuera quizás no digan nada; pero para nosotros que estuvimos allí, que leemos diariamente la prensa "esta" o que sencillamente nos tenemos que pasar toda nuestra vida mirando las pancartas, oyendo el radio (quieras o no), oyendo los discursos (quieras o no), oyendo, oyendo, oyendo... y sin poder decir nada. (ARENAS, 2010, p. 48)
\end{abstract}

Sobre sua posição de escritor, no contexto em que o debate sobre o papel dos intelectuais foi colocado em questão diante da premência das demandas econômicas dos trabalhos braçais da revolução, Arenas prefere preservar sua autonomia de pensamento, num aparente acesso de revolta:

pero si algún día me ofrecen dos lugares: uno donde puedas gritar y outro donde puedas comer, no vacilaré nunca en escoger el primer sitio. Porque, qué es en definitivo lo que justifica la existência del hombre en el mundo sino es el hecho de que puede desarrollar un pensamento. (ARENAS, 2010, p. 49)

Arenas traduz, por meio de suas declarações, o conflito no interior do qual os intelectuais foram submetidos, mas também subverte o sentido produzido pela revolução em torno de seus objetivos econômicos, do trabalho braçal, e consequentemente do próprio sujeito revolucionário e do homem novo que, pode-se auferir das críticas de Arenas, seria alguém desprovido de autonomia crítica. Para Arenas, o que dá sentido ao homem, para o escritor e o intelectual, é a capacidade de pensar, e pensar além das amarras impostas. Mesmo que para pensar se suponha que a

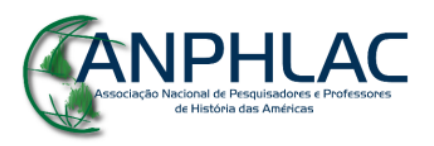

Revista Eletrônica da ANPHLAC, ISSN 1679-1061, №. 24, p. 219-252, Jan./Jun., 2018.

http://revista.anphlac.org.br 
pessoa deva se alimentar, que a nutrição permite um melhor desenvolvimento do pensamento, é evidente que a intenção do escritor, ao preferir um lugar onde se pudesse pensar em vez de comer, foi de denunciar o projeto do regime de obstruir sua liberdade de pensamento, tolher a criação independente em função de uma narrativa e representações da sociedade que adviesse tão somente da versão oficial do Partido Comunista. Pode-se notar isso, mais profundamente, nas seguintes linhas:

[...] Compreendo además que los pueblos y los intelectuales de otros sítios también están asqueados de su realidad (pero no podemos olvidar que el hecho de que ellos puedan manifestar esa repulsión es un privilegio que no poseemos nosotros). Europa, creo, está fatigada por una cultura que ya cumplió su ciclo (ciclo por lo demás grandioso), a nosotros nos aniquila el silencio, la más minuciosa de las misérias y las jornadas de trabajo físico. (ARENAS, 2010, p. 49)

A frustração de Arenas é não poder tratar da realidade tal como a vê, torná-la compreensível além dos termos do realismo socialista. Não lhe falta a intenção, pesa-lhe a impossibilidade. $\mathrm{O}$ escritor admite a amarga conclusão de que nenhum estrangeiro poderia entender o que ele descreve como real por desconhecer as agruras da realidade cubana que experimenta diretamente. No entanto, no interior da ilha, tampouco seria possível, diante da censura que existia. Assim, compara a falta de liberdade de Cuba com a liberdade estável da Europa, onde, malgrado a realidade não fosse perfeita, ao menos poderia manifestar-se as insatisfações, apesar de aparentemente Reinaldo Arenas ignorar que a Europa não se resumia à França, onde estavam seus amigos Jorge e Margarita. Nos dois países vizinhos a oeste dos Pirineus, pesavam sobre a península ibérica as ditaduras derivadas do fascismo de Antônio Salazar em Portugal e de Francisco Franco na Espanha. Todavia, suas palavras traduzem o grau de repressão que o atingia em Cuba, fazendo com que projete sua liberdade fora dali, indiscriminadamente, onde quer que seja; tal impressão decorre do impedimento de se escrever sobre o que se passava e a solidão de não ser compreendido dentro e fora da ilha. Para Arenas, quem vem de fora tem o olhar filtrado pela propaganda oficial. A quem é de dentro de Cuba, como é o seu caso, é proibido dizer o que vive.

Estas cartas são provas da existência de uma forte amizade, tanto pelo período que durou a correspondência, até o último ano de vida de Arenas, quanto pelas situações mais adversas que o escritor enfrentou e narrou para seus correspondentes. Enquanto

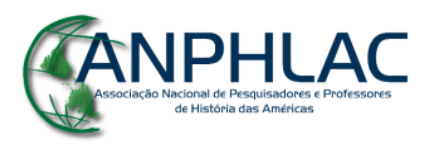

Revista Eletrônica da ANPHLAC, ISSN 1679-1061, №. 24, p. 219-252, Jan./Jun., 2018.

http://revista.anphlac.org.br 
esteve em Cuba, trocaram missivas durante 13 anos sem nenhuma presença física. Várias coisas motivavam a escrita: pedidos, comentários literários, edições estrangeiras de seus livros, política, revolução, sua fuga, mas também a solidão em que vivia, quando reclamava em meados de 1972, “estoy bravo con ustedes pues hace meses que no me escriben" (ARENAS, 2010, p. 61). As cartas o faziam sentir-se próximo de quem estava distante, em sua capacidade de trazer o consolo da sensação das vivas marcas do ausente, em seu doce reconhecimento dos traços de uma mão amiga nas páginas que recebia e respondia. Alegravam-no por possibilitar uma espécie de momento face-a-face com seus amigos. É o fazer-se presente pela escrita (FOUCAULT, 2004).

A escrita epistolar de Arenas representa uma ponte para sua liberdade. Nela, confiou aos amigos uma série de informações e ideias perigosas para o tempo e lugar em que viveu, e que Jorge e Margarita, felizmente, decidiram preservar: há confiança nas coisas que diz que viu, ouviu, sentiu e experimentou. Só assim expressava suas posições políticas, revelava seus planos secretos de escrita, admitia seu isolamento. As palavras de uma carta, como firma Ângela de Castro Gomes (2004), também podem servir de estímulo, consolo, impulso para seguir adiante, e o próprio Arenas o afirmou em algumas delas.

Se para o escritor tais papeis foram redutos de resistência e fôlego para existir e seguir vivendo, para o historiador é um prato cheio em seu ofício. A importância desses documentos para a compreensão do processo revolucionário cubano, para ler as marcas históricas que riscaram a vida de Reinaldo Arenas e como este se constituiu no referido contexto, é dimensionada pela possibilidade de uma reescrita da história riquíssima de sua experiência. Numa escala maior, neste caso, permite progredir na compreensão da relação entre os intelectuais homossexuais e a Revolução Cubana.

Como apontado no início deste artigo, há uma carência nas pesquisas que tratam da relação entre os intelectuais cubanos e a revolução nas primeiras décadas após 1959 que versem especificamente sobre Reinaldo Arenas, porque as investigações costumam ser centradas em suplementos literários os quais o escritor não integrou. Isso faz com que sua participação nos acontecimentos da Revolução Cubana seja sondada sobretudo por sua famosa pentalogia ${ }^{7}$, os escritos do exílio (participação em revistas, como as

\footnotetext{
${ }^{7}$ Enquanto esteve em Cuba, até 1980, Arenas escreveu e conseguiu publicar uma variedade de obras literárias em situações mais adversas, com as seguintes datas de publicação: Celestino antes del alba
}

\section{GANPHLAC}

Revista Eletrônica da ANPHLAC, ISSN 1679-1061, №. 24, p. 219-252, Jan./Jun., 2018.

http://revista.anphlac.org.br 
Revistas Mariel e Vuelta, artigos, documentários, manifestos, entrevistas etc.) no decorrer da década de 1980, e pela autobiografia Antes que anoiteça, concluída em 1990, antes de cometer suicídio.

\section{Os sentidos da revolução, a experiência e as possibilidades da escrita de si}

A revolução produziu sentidos que definiram o significado das coisas, da nação, do ser revolucionário, do ser homem, mulher, patriota, que foram construídos e disseminados dentro de um contexto específico, com influências próprias do desenrolar dos acontecimentos, inseridas nas contingências históricas. Os sentidos de revolução e sujeito revolucionário são próprios do momento em que foram construídos, daí o sentido ser, segundo Spink e Medrado (2013, p. 22):

uma construção social, um empreendimento coletivo, mais precisamente interativo, por meio do qual as pessoas - na dinâmica das relações sociais historicamente datadas e culturalmente localizadas - constroem os termos a partir dos quais compreendem e lidam com as situações e fenômenos à sua volta.

O imaginário revolucionário se compõe de significados que emergem no período de efervescência, de mudanças bruscas e radicais, os "períodos quentes" de Baczko (1985), em que a construção de uma nova ordem implementa novos símbolos, nem sempre tão novos, que definirão a identidade coletiva. Segundo esse autor, através dos imaginários sociais,

uma coletividade designa a sua identidade; elabora uma certa representação
de si; estabelece a distribuição dos papéis e das posições sociais; exprime e
impõe crenças comuns; constrói uma espécie de código de "bom
comportamento", designadamente através da instalação de modelos

(1965), El mundo alucinante (1966), El palacio de las blanquísimas mofetas (1975), Otra vez el mar (1982), entre outros poemas e contos. À exceção de Celestino e uma pequena parte de El mundo alucinante, todas as outras novelas, inclusive esta, foram publicadas no exterior, após terem sido contrabandeadas. Celestino antes del alba, El palacio de las blanquísimas mofetas e Otra vez el mar fazem parte do maior projeto literário do escritor, a sua pentalogia, que ele cunhou de pentagonía, pois se tratam de novelas que narram a agonia de seu personagem principal durante toda a sua vida, desde a infância até a morte. A pentagonía só foi concluída no exílio, quando foi completada pelas obras El color del verano (1991) e El asalto (1991). Em cada uma dessas cinco novelas, o personagem principal possui um nome diferente mas que são codinomes para o próprio Reinaldo Arenas narrar suas agonias e opressões vividas desde o seio familiar às violências perpetradas pelo Estado, nas quais a sexualidade do escritor é bastante evidenciada (PANICHELLI-BATALLA, 2005).

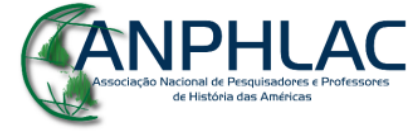

Revista Eletrônica da ANPHLAC, ISSN 1679-1061, №. 24, p. 219-252, Jan./Jun., 2018.

http://revista.anphlac.org.br 
formadores tais como o do "chefe", o "bom súdito", o "guerreiro corajoso", etc. [...] Corresponde ainda a formar as imagens dos inimigos e dos amigos, rivais e aliados, etc. (BACZKO, 1985, p. 309)

Se, no entanto, o contexto molda certos sentidos e um repertório de significados mais ou menos precisos, eles não são estáveis, herméticos, imutáveis. São significados e ressignificados por sujeitos e grupos que o experimentam de alguma maneira diferente do que está dado. Quando um significado se rompe, acontece a "prática discursiva", no sentido em que apregoa Mary Jane Spink e Benedito Medrado (2013), ou seja, produzse, por meio da linguagem, novos sentidos. A produção de novos sentidos acontece no momento de ruptura e diversificação do enunciado. No repertório revolucionário, a palavra revolução, tão incansavelmente repetida, pode tomar diferentes contornos quando retomada por diferentes sujeitos. A ruptura e diversificação do enunciado estão diretamente ligadas à experiência de quem significa, à posição social, à ação, à interpretação da realidade a partir de uma subjetividade que interage no cotidiano. E por essa linguagem (escrita ou falada) ser ação, ela produz consequências.

A escrita afirma um posicionamento, outra linha de argumentação, revela contradições da revolução que assume, através dela, formas peculiares; também realça uma individualidade dissonante, um rompimento com as ordens impostas, uma inadequação política pela denúncia das violências sofridas, pela acusação dos preconceitos sociais e sexuais, mesmo que de maneira indireta. Forma-se enquanto sujeito histórico por meio da escrita de si, no trabalho do próprio eu, na relação com o outro e com o seu contexto (RAGO, 2013, p. 50-51). Arenas não traz, nas cartas aqui abordadas, a sua sexualidade diretamente, mas a repressão que vivenciou por ser homossexual está implícita nas suas críticas à falta de liberdade na ilha, afinal, não foram só por suas ideias políticas que a novela El mundo alucinante (contemporâneo às cartas de 1967, 68 e 69) foi censurada, mas por suas representações homoeróticas que desestabilizavam o ideal de nação revolucionária.

Desde que se exilou de Cuba em 1980 e aportou em Miami, as ideias de Reinaldo Arenas foram consideravelmente divulgadas em círculos de intelectuais cubanos exilados e entre simpatizantes da luta contra o autoritarismo do regime de Fidel Castro, devido às nefastas perseguições políticas e sexuais desencadeadas na ilha após a revolução de 1959. No exílio, Arenas integrou a chamada Generación Mariel, termo

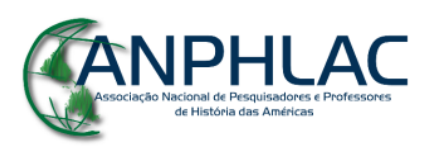

Revista Eletrônica da ANPHLAC, ISSN 1679-1061, №. 24, p. 219-252, Jan./Jun., 2018.

http://revista.anphlac.org.br 
extraído da crise humanitária de 1980, quando uma multidão de aproximadamente 120.000 cubanos saiu de Cuba pelo porto Mariel em direção aos EUA. Compôs esse quadro uma massa heterogênea constituída de pessoas descontentes com o regime, dissidentes políticos, criminosos comuns, homossexuais, prostitutas e deficientes mentais que propositalmente foram enviados pelo regime para fora da ilha, chamados de “escórias" por Fidel Castro. Contudo, de certa forma, a memória histórica desse acontecimento foi restrita a um punhado de intelectuais cubanos exilados (os marielitas) que se congregaram em torno da Revista Mariel, criada em 1983, tendo Arenas a frente como um dos fundadores. Suas edições da década de 1980 foram voltadas para divulgação da literatura do exílio, entrevistas, testemunhos etc. Com isso, suas memórias de escritor homossexual perseguido pelo regime, bem como sua produção literária tiveram uma maior visibilidade (BARQUET, 1998). Além de sua autobiografia Antes que anoiteça, que já possui quatro edições no Brasil ${ }^{8}$, a divulgação da história de vida de Arenas foi impulsionada quando adaptada para o cinema no ano de 2000 com o filme Before Night Falls (Antes do anoitecer), dirigido por Julian Schnabel e protagonizado pelo ator Javier Bardem. Desde então, é notável o aparecimento de pesquisas acadêmicas que tratam da vida e da obra do escritor.

$\mathrm{Na}$ autobiografia, Arenas romantiza os lugares de expressão homossexual de outrora, revelando algo que existia, mas que fora suprimido e minucia exaustivamente relações sexuais homoeróticas como forma de resistência ao regime repressor de Fidel. As várias adversidades que provou, as situações intoleráveis, prisões, fugas e martírios resultam numa intraduzibilidade que atravessa sua narrativa autobiográfica. Reinaldo Arenas recorreu à escrita para tratar do indizível, do inimaginável que sofreu, para resistir à própria destruição, trazer à tona o que recusava a simbolização; quer romper o silêncio, negar o esquecimento; quer, em um termo, testemunhar. Como uma variante da escrita de si, o testemunho traz à tona uma subjetividade de quem atravessou situações-limite. Segundo Marcio Seligmann-Silva (2003, p. 8), o testemunho tem o sentido de "sobreviver", "ter-se passado por um evento limite, radical, passagem essa que foi também um 'atravessar' a 'morte"'. A narrativa de Arenas comporta a dimensão do testemunho, remete ao que de fato ocorreu, expressa as marcas da violência, do

\footnotetext{
${ }^{8}$ Três edições pela Editora Record $(1992,1995,2001)$ e uma pela BestBolso (2009).

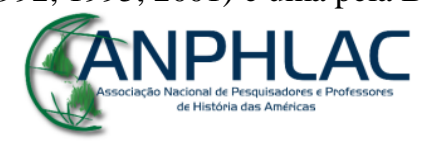

Revista Eletrônica da ANPHLAC, ISSN 1679-1061, №. 24, p. 219-252, Jan./Jun., 2018.

http://revista.anphlac.org.br
} 
medo, da solidão, do isolamento, da opressão e até da morte. Têm o peso da necessidade de dizer, são motivadas por essa necessidade.

Próximo a esse quadro teórico, a experiência de um escritor homossexual tem sido o ponto de partida de boa parte dos trabalhos historiográficos que analisam suas obras, em várias abordagens. É nesse sentido que a literatura de Reinaldo Arenas, seja a autobiografia ou suas novelas, é considerada testemunho histórico, narrando uma experiência de perseguição tanto no seio da família, quando era criança, até a fase madura sob um regime autoritário, numa espécie de extensão, desde o âmbito familiar até o Estado, de uma rede de sujeição que abateu sobre sua vida (PANICHELLIBATALLA, 2005).

$\mathrm{Na}$ sua autobiografia, escrita sob a consciência da proximidade da morte, uma vez que o escritor havia contraído AIDS, Arenas constrói uma imagem de si e de como escolheu se apresentar num dado momento de sua vida. Quer dizer, no final de sua vida. Pelo menos em sua narrativa autobiográfica, construiu-se um sujeito coerente, uma vida linear, perpassada por um único objetivo desde seu nascimento: o prazer homoerótico e a busca da liberdade sexual e intelectual. Na contracapa da edição brasileira, Guillermo Cabrera Infante, escritor cubano exilado desde a década de 1960, assim o definiu num trecho originalmente publicado no periódico El País:

\footnotetext{
Três paixões dominaram a vida e a morte de Reinaldo Arenas: a literatura (não como um jogo, mas como um fogo que consome), o sexo passivo e a atividade política. Das três, a mais dominante foi, sem dúvida, o sexo. Não somente em sua vida, mas também no trabalho. Ele foi o cronista de um país governado não pelo já impotente Fidel Castro, mas pelo sexo... Coroado com um rústico talento que quase alcança a genialidade neste livro póstumo, ele teve uma vida onde o começo e o fim foram verdadeiramente o mesmo: desde o início, um longo e ininterrupto ato sexual...
}

Essa imagem tende a ofuscar a complexidade da experiência de Reinaldo Arenas e da revolução, de como ele estruturou sua vida e foi se constituindo enquanto sujeito justamente por partir de uma premissa, sua homossexualidade, como evidência reificante de sua experiência. Assim, como diz Joan Scott (1998), a relação do sujeito com a linguagem, como este se constituiu enquanto uma diferença no tempo, um homossexual dentro de uma sociedade estruturada numa dominação simbólica heteronormativa, as relações sociais imbricadas, o embate e a apropriação de sentidos internos a esse processo não são tratados, ou seja, a experiência é invisibilizada. Neste

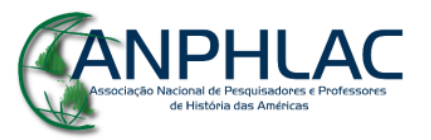

Revista Eletrônica da ANPHLAC, ISSN 1679-1061, №. 24, p. 219-252, Jan./Jun., 2018.

http://revista.anphlac.org.br 
caso, exalta-se uma fração do sujeito, aquela selecionada pelo mecanismo da memória, com um objetivo, um interesse proveniente de sua posição no momento em que escreveu sua autobiografia; e então atribui-se esse sentido a toda a sua vida. A existência ganha uma narrativa incontestavelmente linear, como quis Cabrera Infante em seu comentário, “desde o início, um longo e ininterrupto ato sexual...”.

Se Arenas, do ponto de vista de um de seus leitores, teve uma vida em que do início ao fim foi o mesmo, a saber, um ato sexual ininterrupto, nas cartas se apresenta alguém que problematiza os sonhos não realizados, as promessas não cumpridas, o nacionalismo e o romantismo revolucionários, tão característicos de movimentos de ruptura radical e que se esfacelam nas suas linhas. As posturas políticas no decorrer do tempo não são estáticas; as ideias de igualdade, liberdade, inovação e superação se fragmentam, são relativizadas, ganham uma diferente tonalidade. A resistência que o escritor apresenta em suas cartas diz respeito ao além do corpo sexualizado e execrado, embora este seja um aspecto imperativo em sua vida. Sua escrita epistolar, como espaço clandestino de atuação política, envolve denúncias ao autoritarismo, à censura e, em alguns momentos, à própria esperança da possibilidade de mudança da revolução em Cuba. Vê-se também os desafios de ser escritor nas primeiras décadas do processo revolucionário no momento mesmo em que ocorriam, complexificando o contexto, demonstrando a existência de mundos subterrâneos de atuação que dizem respeito, dessa forma, a outras questões que tornam o horizonte de sua existência bem mais amplo para o pesquisador. Arenas foi afetado de diversas formas, seus interesses não se reduzem a um único campo posto em debate pela revolução, como a sexualidade. Esta atravessa sua escrita, implícita e explicitamente, é verdade, mas não se reduz a ela.

Por fim, as cartas também podem ser consideradas documentos da barbárie, um testemunho, junto com toda a escritura de Arenas no decorrer de sua vida, pois testemunham uma vida, também uma coletividade, que sofreu a violência, que se sentiu silenciada, estigmatizada. Testemunham uma alteridade suprimida no calor dos conflitos travados. Trazem uma visão de mundo destoante, o desejo do que poderia ter sido mas não foi, esperanças, medos que conviveram na correnteza dos acontecimentos e que atestam a ruína de experiências e expectativas que jazem sob o manto do tempo.

Um contexto que tanto se quis homogêneo pela narrativa oficial da revolução, em que todos estavam envolvidos na correnteza revolucionária onde tudo se tornou

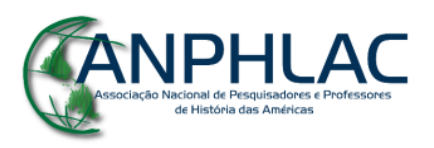

Revista Eletrônica da ANPHLAC, ISSN 1679-1061, №. 24, p. 219-252, Jan./Jun., 2018.

http://revista.anphlac.org.br 
possível através do otimismo e determinação, rumo a um único objetivo do progresso revolucionário, tem suas fissuras nessas cartas preservadas, nesses vestígios de vida, na incontornável expressão da complexidade de um período, das possibilidades do vivido, dos rumos da imaginação registrados na escrita de si. Como tudo o que é histórico, essa fonte vem para nos lançar às intermitências, às contradições, às contingências das experiências da vida. Servem para desestruturar as ideias de unidade.

\section{Referências Bibliográficas}

ALBUQUERQUE, JR. Durval Muniz de. Grito, logo existo: corpo, violência e Estado de Exceção. In: TORNQUIST, Carmen Susana et al. (Orgs.). Leituras de resistência: corpo, resistência e poder. Florianópolis: Ed. Mulheres, 2009.

ANDERSON, Benedict. Comunidades imaginadas. São Paulo: Companhia das Letras, 2008 .

ARENAS, Reinaldo. Antes que anoiteça. Rio de Janeiro: Record, 1995.

ARENAS, Reinaldo. El mundo alucinante: (Una novela de aventuras). Madrid, España: Letras Hispánicas, 2017.

ARENAS, Reinaldo. Otra vez el mar. Barcelona: Editorial Tusquets, 2015.

ARENAS, Reinaldo. Cartas a Margarita y Jorge Camacho (1967-1990). Sevilla: Editorial Point de Lunettes, 2010.

ARENDT, Hannah. Sobre a natureza do totalitarismo: uma tentativa de compreensão. In: ARENDT, Hannah. Compreender: Formação, exílio e totalitarismo (ensaios). São Paulo: Companhia das Letras; Belo Horizonte: Editora UFMG, 2008.

AVIVA, Chomsky. História da Revolução Cubana. São Paulo: Veneta, 2015.

BACZKO, Bronislaw. A imaginação social. In: LEACH, Edmund et al. AnthroposHomem. Lisboa: Imprensa Nacional/Casa da Moeda, 1985.

BARRETO, Teresa Cristófani. A libélula, a pitonisa: Revolução, homossexualismo e literatura em Virgílio Piñera. São Paulo: Ed. Iluminuras, 1996.

BARQUET, Jesús J. Generación Mariel. Revista Encuentro de la Cultura Cubana, 8/9, La Habana, primavera/verano de 1998. Disponível em: https://www.cubaencuentro.com/revista/revista-encuentro/archivo/8-9-primavera-eranode-1998/(filter)/index Acesso em: 29/11/2017.

BEJEL, Emilio. Cuerpos peligrosos en una nación de héroes. Revista Encuentro de la Cultura Cubana, 41/42, La Habana, verano/otoño de 2006. Disponível em: https://www.cubaencuentro.com/revista/content/download/46034/399715/version/2/file/ 4142eb76.pdf Acesso em: 29/11/2017.

\section{GANPHLAC}

Revista Eletrônica da ANPHLAC, ISSN 1679-1061, №. 24, p. 219-252, Jan./Jun., 2018.

http://revista.anphlac.org.br 
BOTOSO, Altamir. O realismo maravilhoso no romance $\mathrm{O}$ mundo alucinante, de Reinaldo Arenas. RevLet - Revista Virtual de Letras, v. 03, nº 01, jan./jul., 2011. Disponível em: http://www.revlet.com.br/artigos/84.pdf Acesso em: 29/11/2017.

CARVALHO, José Murilo de. A formação das almas: o imaginário da República no Brasil. São Paulo: Companhia das Letras, 1990.

COYULA, Mario. El Trinquenio Amargo y la ciudad distópica: autopsia de una utopía. Revistas UNAM, v. 14, n. 56. Disponível em: http://www.revistas.unam.mx/index.php/ archipielago/article/view/19944 Acesso em: 29/11/2017.

COSTA, Adriane Vidal. Intelectuais, política e literatura na América Latina: o debate sobre revolução e socialismo em Cortázar, García Márquez e Vargas Llosa (19582005). (Tese de Doutorado). Universidade Federal de Minas Gerais, Faculdade de Filosofia e Ciências Humanas, Departamento de História, Belo Horizonte, 2009. 413 p.

FERNÁNDEZ, Ana Casado. Reinaldo Arenas: una voz desde el margen y la resistencia. Revista de pensamiento, crítica y estudios literários latino-americanos. Mitologias hoy, v. 2, 2015, p. 205-221.

FIGUEIREDO, Luís Cláudio. A militância como modo de vida: um capítulo na história dos (maus) costumes contemporâneos. Cadernos de Subjetividade / Núcleo de Estudos e Pesquisas da Subjetividade do Programa de Estudos Pós-Graduados em Psicologia Clínica da PUC-SP, v. 1, n. 2 (1993). São Paulo, 1993, p. 205-216.

FORNET, Ambrosio. El Quinquenio Gris: revisitando el término. Revista de la Casa de las Américas, $\mathrm{n}^{\circ}$ 246, 2007, p. 3-16.

FOUCAULT, Michel. A escrita de si. In: FOUCAULT, Michel. O que é um autor? Lisboa: Passagens. 1992.

GOMES, Angela de Castro. Escrita de si, escrita da história: a título de prólogo. In: GOMES, Angela de Castro (Org.). Escrita de si, escrita da história. Rio de Janeiro: FGV, 2004.

GUEVARA, Ernesto. O Socialismo e o Homem em Cuba. In: Textos políticos. São Paulo: Centro Editorial Latino Americano, 1980.

MADERO, Abel Sierra. Sexualidades disidentes en el siglo XIX en Cuba. E.I.A.L., Vol. 16, $\mathrm{n}^{\mathrm{0}} 1,2005$. Fundación Fernando Ortiz, Cuba.

MASEDA, Hector. Los trabajos forzados en Cuba. Dossier El Presidio Político en Cuba. Revista Encuentro de la cultura Cubana, p. 24-27, 2001. Disponível em: http://arch1.cubaencuentro.com/pdfs/20/20hm225.pdf Acesso em: 29/11/2017.

MISKULIN, Sílvia Cezar. 1968 em Cuba: mudanças na política internacional e na política cultural. Revista Esboços, v. 15, n. 20, 2008, p. 47-66.

MISKULIN, Sílvia Cezar. Os intelectuais cubanos e a política cultural da Revolução (1961-1975). São Paulo: Alameda, 2009.

MISKULIN, Sílvia Cezar. História, literatura e homossexualidade em Cuba: o caso de Virgílio Piñera. In: COSTA, Adriane Vidal; BARBO, Daniel (Orgs.). História, Literatura e Homossexualidade. Belo Horizonte: Fino Traço, 2013.

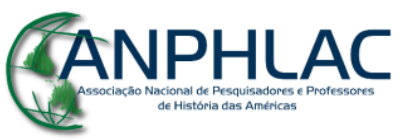

Revista Eletrônica da ANPHLAC, ISSN 1679-1061, №. 24, p. 219-252, Jan./Jun., 2018.

http://revista.anphlac.org.br 
PANICHELLI-BATALLA, Stéphanie. La pentaginia de Reinaldo Arenas: un conjunto de novelas testimoniales y autobiográficas. (Tese Doctoral) Universidad de Granada, Departamento de Filologia Española, Granada, 2005, 675 p.

RAGO, Luzia Margareth. Introdução: Balizas. In: RAGO, Luzia Margareth. A aventura de contar-se: feminismos, escrita de si e invenções da subjetividade. Campinas: Editora da Unicamp, 2013, p. 23-60.

RESOLUÇÕES do Primeiro Congresso Nacional de Educação e Cultura, São Paulo: Livramento, 1980.

ROBAINA, Tomás Fernández. Los homosexuales y la Revolución. Revista Encuentro de la Cultura Cubana, 37/38, La Habana, verano/otoño de 2005. Disponível em: https://www.cubaencuentro.com/revista/revista-encuentro/archivo/37-38-verano-otonode-2005/los-homosexuales-y-la-revolucion-28499 Acesso em: 28/11/2017.

ROJAS, Rafael. Anatomia do entusiasmo: cultura e revolução em Cuba (1959-1971). Tempo Social, v. 19, n. 1, 2007. Disponível em: https://www.revistas.usp.br/ts/article/ view/12535 Acesso em: 20/04/2018.

SPINK, Mary Jane P.; MEDRADO, Benedito. Produção de Sentido no Cotidiano. In: SPINK, Mary Jane (Org.). Práticas discursivas e produção de sentido no cotidiano: aproximações teóricas e metodológicas. Centro Edelstein de Pesquisas Sociais. São Paulo: Editora Cortez, 2013, p. 22-41.

SCOTT, Joan W. A invisibilidade da experiência. Projeto História, São Paulo, (16), fev. 1998, p. 297-325.

SELIGMAN-SILVA, Márcio. Introdução. In: SELIGMAN-SILVA, Márcio (Org.). História, Memória, Literatura: O testemunho na era das catástrofes. Campinas: Editora da Unicamp, 2003, p. 7-44.

SIRINELLI, Jean-Fraçois. Os intelectuais. In: RÉMOND, René. Por uma História Política. Rio de Janeiro: Editora FGV, 2003, p. 231-269.

TEIXEIRA, Rafael Saddi. O ascetismo revolucionário do Movimento 26 de Julho: o sacrifício e o corpo na Revolução Cubana (1952 a 1958). Tese (Doutorado) Universidade Federal de Goiás, Faculdade de História, Goiânia, 2009.

TODOROV, Tzvetan. Introdução à literatura fantástica. São Paulo: Editora Perspectiva, 1975.

VASCONCELOS, Joana Salém. Trabalho voluntário e socialismo nos canaviais cubanos: uma história da safra de 1970. Revista Eletrônica da ANPHLAC, $\mathrm{n}^{\circ} 21$, Jul./Dez., 2016, p. 34-65.

YOUNG, Allen. Los gays bajo la revolución cubana. Madrid: Playor, 1984.

\section{GANPHLAC}

Revista Eletrônica da ANPHLAC, ISSN 1679-1061, №. 24, p. 219-252, Jan./Jun., 2018.

http://revista.anphlac.org.br 